\title{
Article
}

\section{Modern Slavery Responses Need International Business Scholarship}

\author{
Alexander Trautrims ${ }^{1}$ \\ 1 University of Nottingham, UK \\ Keywords: responsible sourcing, supply chain ethics, labor exploitation, modern slavery \\ https://doi.org/10.46697/001c.13539
}

\section{AIB Insights}

Vol. 20, Issue 2, 2020

\begin{abstract}
Modern slavery poses a challenge to many areas of international business and sometimes questions the legitimacy of underlying business models. All businesses are exposed to modern slavery in one way or another through their supply chains, but their actions to address the issue differ hugely. Some blame the complexity and anonymity of international supply chains or the limits of their market power to push for change. These are of course familiar experiences of international business practitioners, but no excuse to avoid action. This article hopes to offer routes and inspiration for international business scholars to contribute to ending modern slavery.
\end{abstract}

\section{INTRODUCTION}

Modern slavery challenges our traditional approaches to business and business research. It questions a puristic focus on financial profits and some of the commonly used mechanisms in global supply chains such as outsourcing and the creation of long - and often unmonitored - global supply chains in which the undercutting of social standards and active ignorance of human rights violations form part of the business model. We can learn from the more ethically oriented businesses already leading against modern slavery in global supply chains, such as cosmetics firm Lush or building materials supplier Marshalls, and from the business responses that were triggered predominantly by recent legislation such as the California Transparency in Supply Chains Act that came into effect in 2012, the UK Modern Slavery Act of 2015, and also by studying the mechanisms that have been established for longer such as the Brazilian Lista Suja (created in 2004). Through these legislative changes modern slavery turned from a niche interest into a widely recognized topic that affects business practice and research: CSR, sustainability reporting, collaboration with stakeholders, ethical investment, supplier development, the responsible recruitment of workers, business regulation, supply chain visibility are only some examples of the many aspects of international business that need new knowledge and approaches to address and challenge modern slavery.

Human rights scholars argue that the legal concept of modern slavery varies between jurisdictions and there is an ongoing debate on what constitutes slavery de jure and de facto and how to define modern slavery (see Nicholson, Dang, \& Trodd, 2018 for an overview of the debate on slavery definitions). In business practice you may hear that trafficking, modern slavery, and forced labor are often used interchangeably, despite being based on different areas of the law and - although connected and overlapping - describe different concepts of exploitation. In the absence of a clear international or scholarly agreement on the definition of modern slavery, the term modern slavery is increasingly used as an umbrella term that includes modern slavery and similar forms of serious exploitation to avoid being dragged into debates about conceptual nuances. More recently I see in my work with supply chain practitioners that some are defining modern slavery through its opposite: decent work.
The approach to aim for decent work - which is recognized in Sustainable Development Goal 8 and the International Labour Organization's Decent Work Agenda - overcomes the conceptual barriers of modern slavery in an implementation-focussed and solution-focussed business and research context. Wherever businesses are creating labor situations that we cannot identify as decent work, we should strive towards improving and preventing these situations, whether it matches a legal definition of modern slavery or not.

\section{IS MODERN SLAVERY THE RESPONSIBILITY OF INTERNATIONAL BUSINESS OR THE RESPONSIBILITY OF GOVERNMENT?}

Modern slavery in supply chains is influenced by many factors, some within the direct or indirect influence of business. Explaining what causes modern slavery is key to developing solutions. Allain et al. (2013) shape the argument of how supply chain and market structures impact the likelihood of modern slavery to occur. They also use the concept of labor chains which have been largely ignored by traditional supply chain management in its focus on optimizing the flow of goods and money.

Businesses will find themselves operating in or sourcing from countries with higher modern slavery risks. The Global Slavery Index, produced by the Walk Free Foundation, measures countries' vulnerability to modern slavery across five dimensions: governance issues; lack of basic needs; inequality; disenfranchised groups; and effects of conflict. These measures assess modern slavery at country level and not at an individual supply chain level, but they can give businesses an initial understanding of the risk levels and context that they operate in. In many countries that perform poorly in the Global Slavery Index, the ability for a business to address these modern slavery risks may be limited or at least different in comparison to countries with robust law enforcement and victim support. In any internationally operating business, the implementation of antislavery policies needs to be adjusted to local context and circumstances, particularly where the state responses to modern slavery are not effective or do not address the underlying causes for modern slavery. 
As New (2015) rightly debated, modern slavery may show us the limits of corporate social responsibility as modern slavery cannot be eradicated by businesses alone without state actors who punish those that commit the crime and ensure access to remedy for victims from those who benefitted from slave labor. Nevertheless, businesses have many levers to support the fight against modern slavery in their global supply chains: they can for example incentivize and train suppliers to provide better labor conditions, offer longer-term contracts with stable capacity demands, and educate workers on their rights and listen to workers voices, but they cannot fully substitute for dysfunctional or absent state structures. The inability to substitute state functions, however, should not be an excuse from providing a safe work environment, scrutinizing suppliers, recruiting workers ethically and addressing the vulnerabilities of their own and their supply chain's workforce as good as they reasonably can.

A key point for scholarly and political debate lies within what efforts we can reasonably expect businesses to undertake within their contextual limitations. The UK's Home Office guidance recommends that Modern Slavery Act statements, which must be produced by all commercial organizations with a turnover of $£ 36$ million carrying out business in the UK, cover six areas: organization structure and supply chains; policies in relation to slavery and human trafficking; due diligence processes; risk assessment and management; key performance indicators to measure the effectiveness of steps being taken; and training on modern slavery and trafficking. It also recommends showing that the organization is 'making year-on-year progress to address those risks and improve outcomes for workers in your business and supply chains' (Home Office, 2018).

When comparing UK Modern Slavery Act statements, the reporting on key performance indicators continues to be the weakest area in statements (Phillips \& Trautrims, 2018). That means business efforts and resource allocation are widely undertaken without the same understanding of cost effectiveness and progress monitoring that we would expect for environmental sustainability or commercial activities in a business. Suitable ways to measure progress on modern slavery and incorporating local circumstances into the measurement will continue to be a challenge for business.

\section{EFFECTIVE RESPONSES TO MODERN SLAVERY REQUIRE CHANGES IN INTERNATIONAL BUSINESS PRACTICE}

In our engagement with businesses and work on comparing UK Modern Slavery Act statements, we can observe businesses who meaningfully respond to modern slavery in their supply chains by building alliances in their industries and across industries, sharing intelligence, and questioning their operational practices. These businesses generally develop well-run supply chains as a good supply chain understanding and visibility are a fundamental pre-requisite to act against modern slavery. This often comes with eliminating unnecessary complexity and non-value adding middlemen.

In a recent project, we investigated Brazil-UK beef and timber supply chains. We were specifically interested in how these supply chains across different legal systems are structured and governed, and how that impacts the risk of modern slavery. We found that the laws and regulations governing these supply chains often only address individual parts or tasks in the supply chain and are not aligned with the connected logic of an end-to-end supply chain (Pinheiro, Emberson, \& Trautrims, 2019). Particularly in the case of beef, the supply chain becomes highly fragmented and - in the current business model - untraceable at the stages prior to the point when cattle are being sold to the large globally-operating beef processors.

Businesses are capable of monitoring their global supply chains for commercially important reasons such as quality or hygiene requirements and hence their monitoring infrastructure can be utilized for purposes like modern slavery prevention. However, supply chain monitoring structures are often only developed for commercial reasons, which tend to stop at an upstream commodity point such as the supply chain stages of raising and selling cattle. This unfortunate economic reality supports the argument that human rights violations in the global supply chain need to be made commercially relevant for companies to commercially justify investment into better monitoring. Responses to modern slavery cannot solely rely on consumer pressure, which has been shown to be less effective than hoped for (Smith \& Johns, 2019), but must involve state mechanisms such as public contract requirements, supply chain governance, and legal responsibility for supply chains.

Regularly, the presence of complex sourcing arrangements and messy global supply chain structures is used as a pragmatist argument against the responsibility of business for modern slavery in their supply chain. The challenge of modern slavery undoubtedly varies between businesses depending -amongst other factors - on their size, the nature of their products and services, traceability, how integrated their supply chains are, and the longevity of relationships with suppliers and customers. Production aspects such as seasonality increase the risk of modern slavery as workers are needed temporarily, often hired through agents or gangmasters, and operational pressures like fruit otherwise rotting in the fields or a construction project running late, may override ethical compliance considerations in operational practice. Many aspects are perfectly within the ability of business to influence, for example, if the business sources directly from producers or through middlemen, how it deals with whistle-blowers, whether it accepts responsibility and offers support for victims found in its supply chain, its own organizational decision and the political power it gives to ethics decision-makers, whether it collaborates with law enforcement in jurisdictions where it is safe to do so, and of course the way it defines and measures performance (Gold, Trautrims, \& Trodd, 2015).

Modern slavery has caused many businesses around the world to collaborate with their competitors. Businesses face similar challenges and have professional communities through which they organize and interact; they often operate in the same areas, have similar requirements, regulation and supply chain structures if they are in the same sector and often share suppliers. It intrinsically makes sense for them to collaborate against modern slavery to share the costs for compliance, monitoring, and development. We can see meaningful and successful collaboration in a variety of sectors and businesses seem generally characterized by a concentration in a small number of actors at a tier of the supply chain that holds power in the global supply chain, for example in construction (see also Allain et al., 2013) where larger businesses exist at the project management and materials suppliers levels, or in the chocolate sector, where a small number of companies buy most of the world's supply of cocoa. Smaller companies, however, do not have the same resources and expertise, so good practice examples for smaller companies are often based on their ability 
to form more direct and deeper relationships with producers and workers. In many cases such approaches of direct and deep relationships with producers tend to focus on a niche premium market of ethically conscious customers, and we need to learn how ethical practice can be rolled out to mainstream markets and indeed become an entry ticket.

The active work against modern slavery by international businesses and the implementation of mechanisms to ensure decent work are usually associated with adding costs for monitoring, compliance, and sometimes higher labor costs. Those businesses acting against modern slavery are therefore carrying a higher cost whilst others are freeriding as they also benefit from supplier improvements and reduced vulnerability of workers. The dilemma that the economic benefits of slavery-free supply chains are largely at a societal level and available to the benefit of all businesses operating in it, whereas the costs are to individual businesses is a flaw that must be overcome and a reason why many business practitioners voice support for stricter modern slavery legislation and its enforcement.

\section{HOW CAN INTERNATIONAL BUSINESS \\ SCHOLARSHIP HELP TO ERADICATE MODERN SLAVERY?}

There are many open questions on business responses to modern slavery, what works, and how proven solutions can be transferred into different contextual settings. International business scholarship provides the necessary research approaches and knowledge basis about international business organizations, their behaviors, logics, recruitment, considerations and decision-making processes. Often in business scholarship we follow what we see in practice and can conceptualize and explain. But modern slavery research needs to go further; we need to explain and recommend changes to business practice, highlight best practices, and discuss how to spread best practices.

Researching modern slavery must be problem-centric, interdisciplinary, and open to a variety of theoretical lenses, methods, and concepts of understanding. Leaving our academic comfort zones and appreciating a diversity of approaches and angles is key to this challenge. In my research on modern slavery in supply chains, I have worked with computer scientists, medical practitioners, mathemati- cians, food scientists, climate change experts, historians, economists, sociologists, construction engineers, and of course human rights lawyers to address specific modern slavery problems and situations. While I cannot pretend that I have always understood the depths of their disciplines, working with scholars across disciplines stretched and often enough broke the narrow conceptual boundaries of my home discipline.

Modern slavery also questions how we teach international business. In my own area of global supply chain management, we teach students to analyze supply markets and supplier portfolios in a structured way to categorize suppliers into those they should build strategic long-term relationships with and those suppliers they should squeeze as hard as possible. It does not take much reflection in which of these supplier categories the risks for exploitation may be higher (see for example Schleper, Blome, \& Wuttke, 2017). To produce a generation of practitioners with the ability to create new approaches of doing business, social sustainability considerations and business ethics must be integrated in business school curricula not just as a separate module but embedded within each area of business education.

Modern slavery fundamentally questions the current operational model of international business and highlights injustice and human suffering for the benefit of others' consumption, desires and ignorance. It requires us to work jointly with other academic fields, to utilize new data sources, to work with policymakers and practitioners, and to shift towards problem-centric and practice-leading scholarship.

\section{ABOUT THE AUTHOR}

Alexander Trautrims (alexander.trautrims@nottingham.ac.uk) is Associate Director, The Rights Lab, University of Nottingham, and Associate Professor in Supply Chain and Operations Management, Nottingham University Business School. Dr Trautrims' research is interested in the detection, prevention and eradication of modern slavery in supply chains. He enjoys conducting his research in close interaction with practitioners and policymakers. He helped produce the first modern slavery guidelines for procurement in UK construction and modern slavery risk analyses for public procurement entities, and his work has been referred to in Parliamentary debate and Select Committees. 


\section{REFERENCES}

Allain, J., Crane, A., LeBaron, G., \& Behbahani, L. 2013. Forced labour's business models and supply chains. Joseph Rowntree Foundation \& Queens University Belfast. http://www.jrf.org.uk/report/force d-labour\%E2\%80\%99s-business-models-and-supplychains.

Gold, S., Trautrims, A., \& Trodd, Z. 2015. Modern slavery challenges to supply chain management. Supply Chain Management: An International Journal, 20(5): 485-494.

Home Office. 2018. Slavery and human trafficking in supply chains: Guidance for businesses. https://ww w.gov.uk/government/publications/transparency-in-s upply-chains-a-practical-guide.

New, S. J. 2015. Modern slavery and the supply chain: The limits of corporate social responsibility? Supply Chain Management: An International Journal, 20(6): 697-707.

Nicholson, A., Dang, M., \& Trodd, Z. 2018. A Full Freedom: Contemporary Survivors' Definitions of Slavery. Human Rights Law Review, 18(4): 689-704.
Phillips, A., \& Trautrims, A. 2018. Agriculture and Modern Slavery Act Reporting: Poor Performance Despite High Risks. Office of the Independent AntiSlavery Commissioner and University of Nottingham Rights Lab. http://www.antislaverycommissioner.co.u $\mathrm{k} /$ media/1220/modern-slavery-act-and-agriculture-p oor-performance-briefing.pdf.

Pinheiro, S. M., Emberson, C., \& Trautrims, A. 2019. 'For the English to see' or effective change? How supply chains are shaped by laws and regulations, and what that means for the exposure of modern slavery. Journal of the British Academy, 7 (s1): 167-190.

Schleper, M. C., Blome, C., \& Wuttke, D. A. 2017. The Dark Side of Buyer Power: Supplier Exploitation and the Role of Ethical Climates. Journal of Business Ethics, 140(1): 97-114.

Smith, A., \& Johns, J. 2019. Historicizing Modern Slavery: Free-Grown Sugar as an Ethics-Driven Market Category in Nineteenth-Century Britain. Journal of Business Ethics. https://doi.org/10.1007/ s10551-019-04318-1. 